Article

\title{
Structure-Activity Relationship Assessment of Sophorolipid Ester Derivatives against Model Bacteria Strains
}

\author{
Filbert Totsingan ${ }^{1, *}$, Fei Liu ${ }^{2}$ and Richard A. Gross ${ }^{2, *}$ \\ 1 Department of Chemistry and Chemical Biology, Rensselaer Polytechnic Institute, Troy, NY 12180, USA \\ 2 Center for Biotechnology and Interdisciplinary Studies (CBIS), Rensselaer Polytechnic Institute, \\ Troy, NY 12180, USA; 1.feigz@gmail.com \\ * Correspondence: totsif@rpi.edu (F.T.); grossr@rpi.edu (R.A.G.)
}

check for updates

Citation: Totsingan, F.; Liu, F.; Gross, R.A. Structure-Activity Relationship Assessment of Sophorolipid Ester Derivatives against Model Bacteria Strains. Molecules 2021, 26, 3021. https://doi.org/10.3390/ molecules 26103021

Academic Editors: Paola Costanzo, Antonio De Nino and

Loredana Maiuolo

Received: 29 April 2021

Accepted: 16 May 2021

Published: 19 May 2021

Publisher's Note: MDPI stays neutral with regard to jurisdictional claims in published maps and institutional affiliations.

Copyright: (C) 2021 by the authors Licensee MDPI, Basel, Switzerland. This article is an open access article distributed under the terms and conditions of the Creative Commons Attribution (CC BY) license (https:// creativecommons.org/licenses/by/ $4.0 /)$.

\begin{abstract}
Sophorolipids (SLs) are glycolipids that consist of a hydrophilic sophorose head group covalently linked to a hydrophobic fatty acid tail. They are produced by fermentation of nonpathogenic yeasts such as Candida Bombicola. The fermentation products predominantly consist of the diacetylated lactonic form that coexists with the open-chain acidic form. A systematic series of modified SLs were prepared by ring opening of natural lactonic SL with $n$-alkanols of varying chain length under alkaline conditions and lipase-selective acetylation of sophorose primary hydroxyl groups. The antimicrobial activity of modified SLs against Gram-positive human pathogens was a function of the $n$-alkanol length, as well as the degree of sophorose acetylation at the primary hydroxyl sites. Modified SLs were identified with promising antimicrobial activities against Gram-positive human pathogens with moderate selectivity (therapeutic index, $\mathrm{TI}=\mathrm{EC}_{50} / \mathrm{MIC}_{B \text { cereus }}=6-33$ ). SL-butyl ester exhibited the best antimicrobial activity $(\mathrm{MIC}=12 \mu \mathrm{M})$ and selectivity $(\mathrm{TI}=33)$ among all SLs tested. Kinetic studies revealed that SL-ester derivatives kill B. cereus in a time-dependent manner resulting in greater than a 3-log reduction in cell number within $1 \mathrm{~h}$ at $2 \times \mathrm{MIC}$. In contrast, lactonic SL required $3 \mathrm{~h}$ to achieve the same efficiency.
\end{abstract}

Keywords: sophorolipids; antimicrobial activity; structure-activity relationship; selectivity; bacterial resistance

\section{Introduction}

Bacterial resistance has spread worldwide and is now causing a global health crisis, which requires a global action plan [1]. For example, it is reported that more than 2.8 million antibiotic-resistant infections occur in the United States each year, and more than 35,000 people die as a result [2], while at least 37,000 people die in the EU each year as a direct consequence of healthcare-related infections [3]. One major concern is that the number of approved antibiotics capable of combating bacterial resistance has consistently dropped over the years [4], thus suggesting an urgent need for new drugs that will address this worldwide problem. In drug discovery and development, it is essential to use strategies that reduce the likelihood of new therapeutics being potential targets for the development of pathogen resistance. One of the strategies to circumvent such outcomes is to focus on membraneactive drug development. This approach is favorable since it leads to rapid pathogen eradication, multi-target effects, and activity against slow-growing bacteria [5].

Sophorolipids (SLs) are a family of glycolipids produced by fermentation of nonpathogenic yeasts such as Candida Bombicola [6,7]. They consist of a hydrophilic sophorose head covalently linked to a hydrophobic fatty acid tail. The fermentation products are predominantly lactonic forms with various degrees of acetylation on the sophorose head (Figure 1a) that coexist with opened chain acidic forms [8-10]. Modified SLs possess great potential as emulsifying agents [10-12] and were also found to exhibit a broad range of biological properties, including antibacterial [13], antiviral [14], anticancer [15,16], and anti-inflammatory [17] properties; spermicidal agents [14]; and modulators to control 
the severity of sepsis [18]. Despite their promising bioactivities, there remains a gap in our understanding of natural and modified SL structure-activity relationships. Efforts to improve the performance of natural SLs include varying the hydrophobic tail length or the sophorose structure during the biosynthetic processes $[19,20]$ and genetic engineering to prepare other structural variants [21]. However, these approaches are often limited by a narrow range of structure variations that are produced in substantially lower yields than that produced by the wild-type organism. One promising and practical alternative is the use of chemo-enzymatic synthetic approaches to prepare a broad range of SL derivatives from natural lactonic SLs [22-25]. For instance, SL esters have been synthesized by ring opening of lactonic SLs with various alcohols under alkaline conditions [22]. Selective acylation on the two-primary hydroxyl groups of the sophorose unit has also been carried out by lipasecatalyzed reactions [24]. The change in surface tension and emulsifying properties of SL esters with increasing chain length has also been investigated [10-12,23]. Thus, the chemoenzymatic approach provides a wide range of modified SLs to interrogate SL structureactivity relationships.

a)

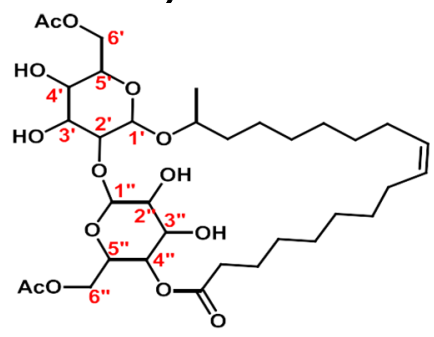

Lactonic SL diacetate, LSL[6'Ac,6’'Ac]

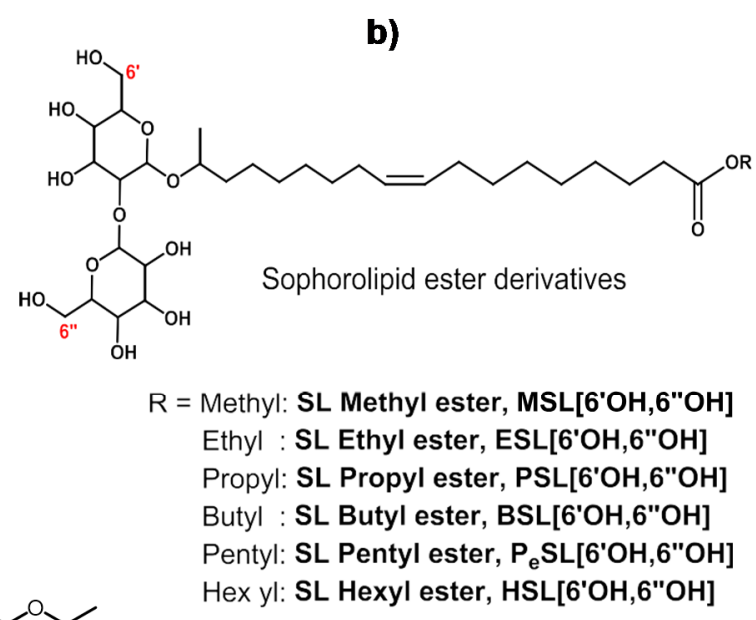

c)

Pentyl: SL Pentyl ester, Pes[6'OH,6"OH]
Hex yl: SL Hexyl ester, HSL[6'OH,6"OH]

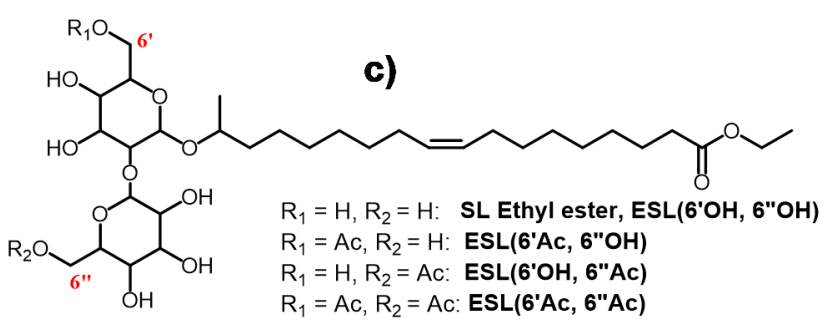

Figure 1. Chemical structures of (a) lactonic SL, (b) SL esters with increasing lengths, and (c) SL-ethyl ester with different degrees of acetylation.

In this study, a family of SL esters (Figure 1b) with increasing chain length and degree of acetylation of the sophorose moiety (Figure 1c) were synthesized and studied for their potential as antimicrobial agents. Structure-activity relationships were investigated, and the ability of these SL derivatives to prevent resistance to human pathogens was evaluated. To gain insights into their mechanism of action, their membrane depolarization capability was assessed. The cumulative results presented herein are promising and provide a foundation that will guide further development of modified SL antimicrobials that are increasingly potent, and exhibit broad-spectrum activity and higher selectivity towards microbial pathogens.

\section{Results and Discussion}

\subsection{In Vitro Antibacterial Efficacy and Structure-Activity Relationship of SL Derivatives}

To assess the structure-activity relationship (SAR) of SLs, a family of SL-esters was synthesized from natural lactonic SL by transesterification using sodium alkoxides of different lengths (Figure 1b). The antibacterial activity of these SL derivatives was evaluated by testing the minimum inhibitory concentration (MIC) against E. coli and several Grampositive bacteria. The MICs of SL-methyl ester against B. cereus, B. subtilis, S. aureus, 
and L. innocua were estimated to be 50,50, 200, $100 \mu \mathrm{M}$, respectively (Table 1 ). As the length of the ester moiety increases, the MIC generally decreases, reaching the lowest values with SL-butyl ester against all tested pathogens $(12,12,100$, and $12 \mu \mathrm{M}$ against B. cereus, B. subtilis, S. aureus, and L. innocua, respectively). The SL-butyl ester exhibited superior or equivalent activity relative to natural LSL for B. cereus, B. subtilis, and L. innocua, and to the control antibiotic, streptomycin. SL-pentyl ester was only active against B. cereus and L. innocua. Further increase in the ester chain length ( $\mathrm{n}>5$, i.e., SL-hexyl ester) did not show any antibacterial activity up to $200 \mu \mathrm{M}$. This loss of activity likely indicated that longer carbon chain esters failed to confer sufficient hydrophilicity to maintain a good hydrophilic-hydrophobic balance. Furthermore, LSL and all the SL-ester derivatives exhibited poor activity against E. coli $(\mathrm{MIC}>200 \mu \mathrm{M})$. The lack of activity against $E$. coli is likely due to the presence of an outer membrane that acts as an additional barrier, as well as other defense pathways that are not present in Gram-positive bacteria [26]. LSL selective activity against Gram-positive strains was previously reported by Kim et al. [27].

Table 1. Effect of SL-ester chain length on minimum inhibitory concentrations (MICs).

\begin{tabular}{|c|c|c|c|c|c|c|}
\hline SLs & B. cereus $^{1}$ & B. subtilis ${ }^{1}$ & $\begin{array}{l}\mathrm{MIC}(\mu \mathrm{M}) \\
\text { S. aureus }^{1}\end{array}$ & L. innocua ${ }^{2}$ & E. coli $^{1}$ & TI \\
\hline Lactonic SL ${ }^{3}$ & 25 & 12 & 25 & 50 & $>200$ & 2 \\
\hline SL-methyl ester & 50 & 50 & 200 & 100 & $>200$ & $>8$ \\
\hline SL-ethyl ester & 50 & 50 & 200 & 50 & $>200$ & 6 \\
\hline SL-propyl ester & 25 & 25 & 100 & 25 & $>200$ & 16 \\
\hline SL-butyl ester & 12 & 12 & 100 & 12 & $>200$ & 33 \\
\hline SL-pentyl ester & 12 & $>200$ & $>200$ & 12 & $>200$ & 17 \\
\hline SL-hexyl ester & $>200$ & $>200$ & $>200$ & $>200$ & $>200$ & - \\
\hline SL-octyl ester & $>200$ & $>200$ & $>200$ & $>200$ & $>200$ & - \\
\hline Streptomycin & 12 & 12 & 3 & 24 & 12 & - \\
\hline
\end{tabular}

${ }^{1}$ Incubation time: $16 \mathrm{~h} .{ }^{2}$ Incubation time: $30 \mathrm{~h} .{ }^{3}$ Natural component used to prepare SL esters. Therapeutic index (TI) was calculated as $\mathrm{EC}_{50}$ macrophage $/ \mathrm{MIC}_{B}$. Cereus. $\mathrm{EC}_{50}$ was determined as concentration causing $50 \%$ killing of macrophage after $16 \mathrm{~h}$.

The degree of acetylation was reported to substantially affect several SL properties, including oil phase emulsification as well as antibacterial, spermicidal, and anti-HIV activities $[14,23,28]$. To assess the extent that the degree and site of acetylation have on SL antibacterial efficacy, the MICs of the SL-ethyl ester acetylated at the 6'- and/or $6^{\prime \prime}$-positions of the sophorose unit were determined, and the results are summarized in Table 2. For the mono-acetylated SL-ethyl ester, the site of acetylation did not influence the MIC against B. subtilis, S. aureus, and L. innocua. However, monoacetylation decreased the MIC against B. subtilis, S. aureus, and L. innocua from 50 to $25 \mu \mathrm{M}$. While increasing the degree of acetylation so that both the $6^{\prime}$ - and $6^{\prime \prime}$-positions were acetylated decreased the MIC to $12 \mu \mathrm{M}$ for $B$. Cereus, it did not exhibit any antibacterial activity against $B$. subtilis, S. aureus, or L. innocua. These results indicate that SL-ester chain length, sophorose unit degree of acetylation, and cell morphology all play an important role in antibacterial activity. These results are consistent with a previous study on the effect of acetylation degree on the antibacterial activity of LSL [28].

Table 2. Effect of degree of acetylation on minimum inhibitory concentrations.

\begin{tabular}{|c|c|c|c|c|}
\hline \multirow{2}{*}{ SLs } & \multicolumn{4}{|c|}{$\operatorname{MIC}(\mu \mathrm{M})$} \\
\hline & B. Cereus $^{1}$ & B. subtilis ${ }^{1}$ & L. innocua ${ }^{2}$ & E. coli ${ }^{1}$ \\
\hline $\mathrm{ESL}-\left(6^{\prime} \mathrm{OH}, 6^{\prime \prime} \mathrm{OH}\right)^{3}$ & 50 & 50 & 50 & $>200$ \\
\hline ESL- $\left(6^{\prime} \mathrm{Ac}, 6^{\prime \prime} \mathrm{OH}\right)$ & 25 & 25 & 25 & $>200$ \\
\hline ESL- $\left(6^{\prime} \mathrm{OH}, 6^{\prime \prime} \mathrm{Ac}\right)$ & 25 & 25 & 25 & $>200$ \\
\hline $\mathrm{ESL}-\left(6^{\prime} \mathrm{Ac}, 6^{\prime \prime} \mathrm{Ac}\right)$ & 12 & $>200$ & $>200$ & $>200$ \\
\hline
\end{tabular}

${ }^{1}$ Incubation time: 16 h. ${ }^{2}$ Incubation time: 30 h. ${ }^{3}$ ESL: SL-ethyl ester. 


\subsection{Time-Kill Studies}

To further investigate if the growth inhibition was associated with cell death, a killing kinetic study was conducted on B. cereus. B. cereus inocula $\left(10^{7} \mathrm{CFU} / \mathrm{mL}\right)$ were exposed to SL derivatives at $1 \times \mathrm{MIC}, 2 \times \mathrm{MIC}$, and $4 \times \mathrm{MIC}$ in PBS buffer at $\mathrm{pH} 7.4$. At $15 \mathrm{~min}, 45 \mathrm{~min}$, $1 \mathrm{~h}$, and $3 \mathrm{~h}$, aliquots were spread onto agar plates for cell counting. As shown in Figure 2, all SL derivatives tested exhibited a time-dependent bactericidal activity. Cells treated with $2 \times$ MIC and $4 \times$ MIC of SL-esters displayed a $>3 \log$ reduction $(>99.9 \%$ reduction) in cell number within $1 \mathrm{~h}$ (Figure 2B-D), while lactonic SL reached the same level of killing in about $3 \mathrm{~h}$ (Figure 2A). This result shows that, at least with B. cereus, natural lactonic SL is less effective in killing this bacterium than the modified SL-ester derivatives, thus showing the benefit of molecular editing in enhancing the killing efficiency of sophorolipids.
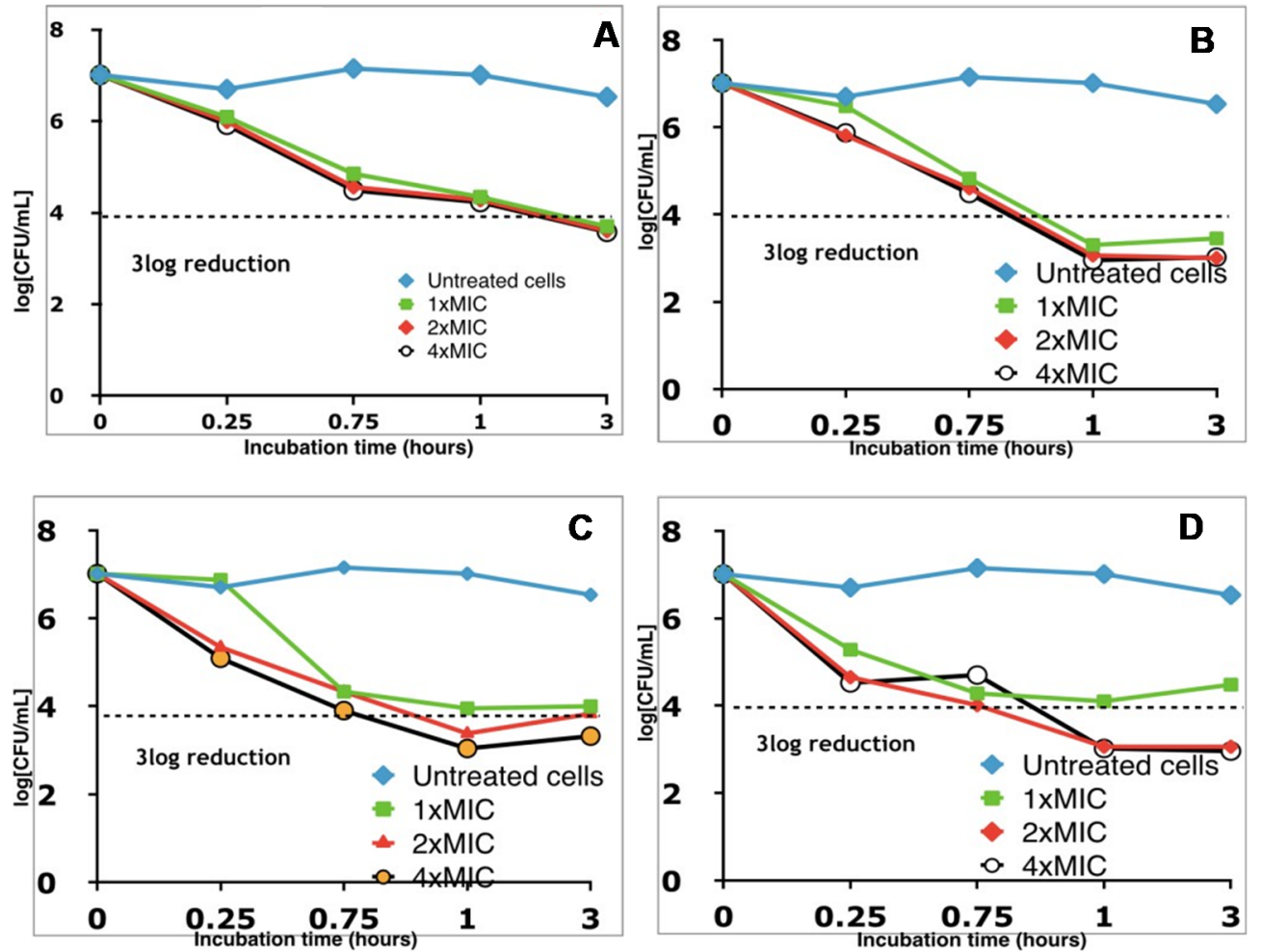

Figure 2. Time-kill study of sophorolipid ester derivatives against B. cereus: (A) lactonic SL; (B) SL-methyl ester; (C) SLpropyl ester; (D) SL-butyl ester.

\subsection{Membrane Depolarization Assay}

To probe the role of LSL and the SL-esters as membrane-active agents, dye leakage experiments were carried out. Polymyxin B, a well-known membrane-active agent, was used as a positive control. Polymyxin B is a cyclic peptide with long, hydrophobic tails that can insert into cell membranes causing cell lysis. First, time-course membrane-depolarizing studies were conducted (Figure 3A). At time $0 \mathrm{~min}$, the fluorescent probe, diS-C3-(5), exhibited a strong fluorescence signal. Upon addition of B. cereus cells at $2 \mathrm{~min}$, a rapid decay in fluorescence intensity was observed due to self-quenching caused by migration of the probe into membranes. Subsequent addition of the SL-esters at $4 \mathrm{~min}$ led to a sharp increase in the fluorescence signal, thus indicating enhanced permeability of the cell membrane driven by the presence of the SL derivative. This is consistent with the time-kill studies that showed rapid bactericidal activities of SLs on B. cereus. Endpoint fluorescence data were recorded at $t=60 \mathrm{~min}$ and are displayed in Figure 3B. The results revealed that all modified SL-esters have a high ability to enhance membrane permeability to an extent that was similar to the positive control (polymyxin B). In contrast, LSL exhibited a non-significant 
ability to enhance cell membrane permeability. This suggests that the killing mechanism of LSL differs from that of SL-esters. The results also showed that SL esters with longer hydrophobic carbon chains (C6-C8) have good cell membrane permeability, despite that they exhibited no antimicrobial activity. This suggests that while membrane permeability is implicated in SL-ester activity, other mechanistic pathways are involved.
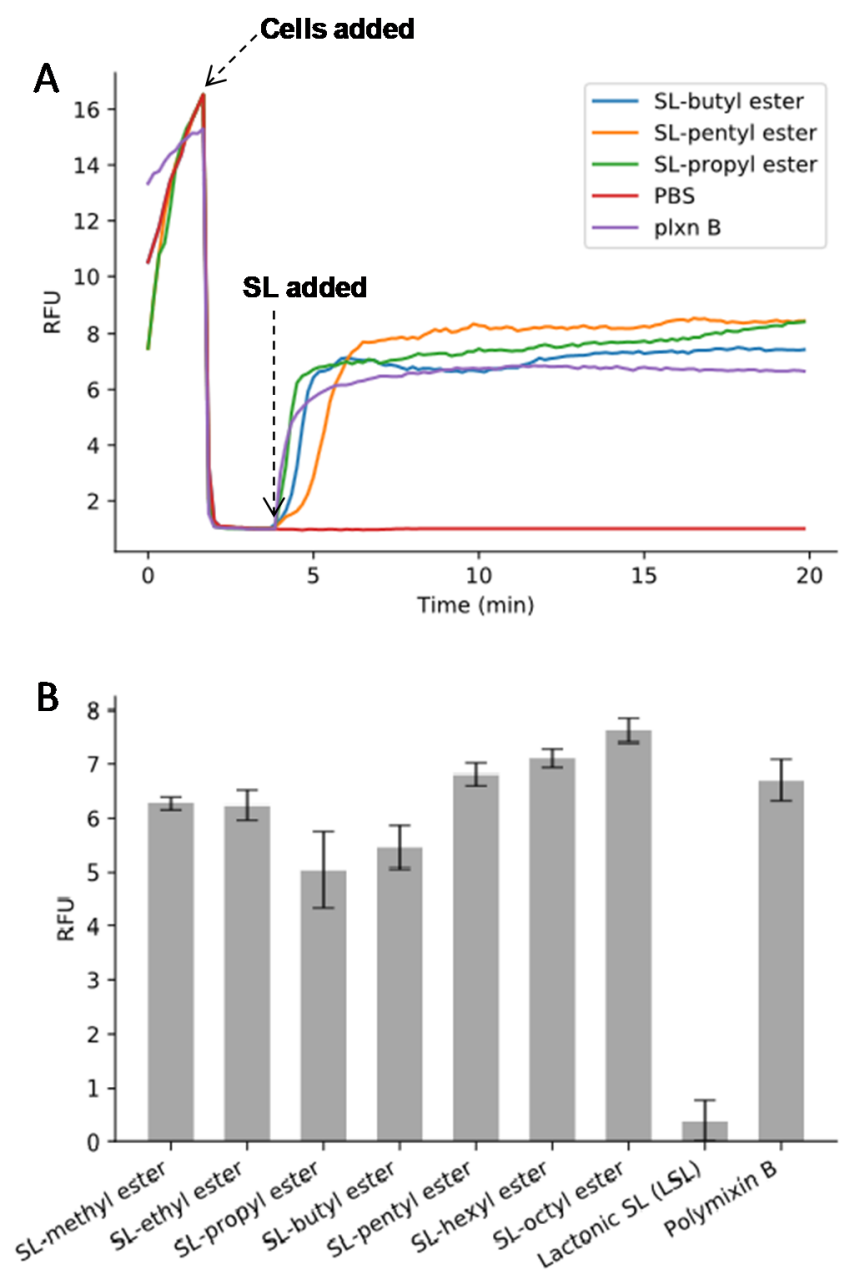

Figure 3. Dye leakage assay of SL esters: (A) time dependence of fluorescence response; (B) endpoint fluorescence intensity measured at $\mathrm{t}=60 \mathrm{~min}$. Polymyxin B (plxn B) was used as a positive control.

\subsection{In Vitro Cytotoxicity}

A potential antimicrobial candidate must selectively kill pathogen cells without harming the host mammalian cells. To test the ability of SLs to effectively discriminate between bacteria and mammalian cells, a cytotoxicity assay was previously reported by our team [17]. The SL-methyl ester exhibited the lowest toxicity with no significant cell reduction at $400 \mu \mathrm{M}$ after $16 \mathrm{~h}$ incubation. SL-ethyl, propyl, and butyl esters exhibited low to no cytotoxicity up to $100-200 \mu \mathrm{M}$, which is much higher than MICs against most strains tested herein (12-50 $\mu \mathrm{M}$ for B. cereus, B. subtilis, and L. innocua). The SL-octyl ester was the most toxic of the SL-ester series, possibly due to its high hydrophobicity and affinity to cell membranes. Similarly, previous work with antimicrobial peptides (AMPs) showed that increasing their hydrophobicity enhanced their binding affinity to mammalian cell membranes $[29,30]$. In comparison to the ester series, lactonic SL was found to exhibit the highest cytotoxicity, with roughly $50 \%$ reduction in cell viability occurring at $50 \mu \mathrm{M}$, thus suggesting that molecular editing not only improved its antimicrobial activity but also lowered its toxicity against mammalian cells. The therapeutic index (TI) is a parameter commonly used to determine potential drug selectivity. TI values were 
estimated as $\mathrm{EC}_{50} / \mathrm{MICB}$. cereus, where $\mathrm{EC}_{50}$ is the concentration that corresponds to $50 \%$ cell death after $16 \mathrm{~h}$ incubations. Table 1 shows that molecular editing largely increased the TI relative to the natural parent lactonic SL. SL butyl ester exhibited the highest TI, which was $16 \times$ higher than that of lactonic SL. Generally, membrane-active agents are not considered for systemic administration directly, because of relatively low selectivity. Thus, designing suitable formulations and selecting suitable dose ranges are important in drug development. One successful clinical example is amphotericin B that was applied as a liposomal formulation, which largely decreased the side effect caused by high toxicity [31].

\section{Materials and Methods}

\subsection{Materials and Reagents}

Novozym 435 was obtained from Novozymes (Copenhagen, Denmark). Lipase PS-C was purchased from Sigma-Aldrich (Milwaukee, WI, USA). Sodium metal (large pieces in kerosene) was purchased from Fisher Scientific (Pittsburgh, PA, USA). 3,3'-Dipropylthia dicarbocyanine iodide (diS-C3(5)) and polymyxin B were purchased from Sigma-Aldrich. Tetrahydrofuran (THF), chloroform $\left(\mathrm{CHCl}_{3}\right)$, methanol $\left(\mathrm{CH}_{3} \mathrm{OH}\right)$ and dimethyl sulfoxide (DMSO) were purchased from Fisher Scientific (Pittsburgh, PA, USA). All bacteria culture media and agars were purchased from Sigma-Aldrich (Milwaukee, WI, USA). All other chemicals and solvents were purchased in the highest available purity from Sigma-Aldrich and were used without further purification.

\subsection{SL Synthesis}

Lactonic SL and SL esters were prepared with good purity (>95\%) following the experimental procedures previously reported by us [6,7,22-24]. In brief, in a round-bottom flask equipped with a reflux condenser, dry diacetyl lactonic SL $(29 \mathrm{mmol})$ was dissolved in the corresponding alcohol $(40 \mathrm{~mL})$. To this mixture, $10 \mathrm{~mL}$ of sodium alkoxide was slowly added, which was prepared separately by adding a small piece of Na metal (170 mg, $0.25 \mathrm{eq}$ ) in the corresponding alcohol. The resulting mixture was refluxed (or heated at $\left.100{ }^{\circ} \mathrm{C}\right)$ for $3 \mathrm{~h}$, and the reaction was monitored by TLC $\left(\mathrm{CHCl}_{3} / \mathrm{CH}_{3} \mathrm{OH}\right.$, staining solution: cerium ammonium molybdate (CAM)). Upon completion, the reaction mixture was cooled to room temperature, acidified with $1 \mathrm{M} \mathrm{HCl}$ or glacial acetic acid to $\mathrm{pH} 4-5$, and concentrated by rotoevaporation. Precipitation in ice-cold water $(0.5 \mathrm{~L})$, followed by filtration and dryness under vacuum, yielded the desired product as an off-white solid c (80-85\%). Longer alkyl chain SL esters (C4-C8) were further purified by flash chromatography. The SL esters were characterized by ${ }^{1} \mathrm{H}$ NMR and LC-MS.

Selective acetylation of the sophorose primary hydroxyls was achieved using two different immobilized lipases (lipase PS-C and Novozym 435). To a solution of SL-ethyl ester $(4.0 \mathrm{~g}$; $6.14 \mathrm{mmol})$ and vinyl acetate (5 or $10 \mathrm{eq})$ in dry THF $(50 \mathrm{~mL})$, either lipase PS-C (1.23 g) for $6^{\prime \prime}$-acetylation or Novozym 435 (1.5 g) for $6^{\prime}$ - and $6^{\prime}, 6^{\prime \prime}$-acetylation was added. The resulting mixture was stirred at $40{ }^{\circ} \mathrm{C}$ under an $\mathrm{N}_{2}$ atmosphere, and the reaction progress was monitored by TLC. Upon completion, the enzyme was filtered out, followed by washing with THF (twice). After removal of solvent, the residue was subjected to silica gel column chromatography using chloroform/methanol as eluent (gradient: from $95 / 5$ to $80 / 20$ ) to afford the final products as off-white solids (75-85\%).

\subsection{Bacteria Strain Culture and Antibacterial Testing}

Bacteria strains Staphylococcus aureus (ATCC 33807), Bacillus cereus (ATCC 4342), Bacillus subtilis (ATCC 21332), Listeria innocua (ATCC 33090), and Escherichia coli (ATCC 53323) were provided by Ravi Kane's lab at Rensselaer Polytechnic Institute. Mueller-Hinton broth (MHB) was used for the Staphylococcus aureus culture, while tryptic soy broth (TSB) was used for the other strains. All strains were grown to the stationary phase for $24 \mathrm{~h}$ at $37^{\circ} \mathrm{C}$ with agitation at $220 \mathrm{rpm}$. After overnight incubation, cultures were diluted to $5 \times 10^{6} \mathrm{CFU} / \mathrm{mL}$ prior to use. 
The minimum inhibitory concentration (MIC) was determined using the microdilution technique. Modified sophorolipid (SL) derivatives were dissolved in DMSO to make $2 \mathrm{M}$ stock solutions. A dilution series was made by diluting the stock solution to a range of concentrations from $200 \mu \mathrm{M}$ to $4 \mu \mathrm{M}$ and a final volume of $100 \mu \mathrm{L}$ in $10 \%$ DMSO/phosphate-buffered saline (PBS) in each well of a 96-well plate. Bacterial inocula $\left(100 \mu \mathrm{L}, 5 \times 10^{6} \mathrm{CFU} / \mathrm{mL}\right)$ were added to each well, and the final DMSO concentration was $5 \%$. Wells containing the same volumes of DMSO/PBS buffer and culture medium, with and without bacteria, were used as positive and negative controls, respectively. Streptomycin was used for comparison. The plate was then incubated with shaking for $16-30 \mathrm{~h}$ at $37^{\circ} \mathrm{C}$ to ensure that cultures had reached stationary phase growth and the absorbance readings were recorded at a wavelength of $600 \mathrm{~nm}$ using an absorbance microplate reader. Absorbance data from $16-30 \mathrm{~h}$ were used to calculate the percent inhibition for each test condition. MIC was recorded as the lowest concentration of drug that inhibited more than $90 \%$ of bacterial growth. All assays were carried out in triplicate.

\subsection{Time-Kill Studies}

The bactericidal activity of modified SLs against Bacillus cereus was assessed by incubating $1 \mathrm{~mL}$ of microbial suspensions $\left(\sim 10^{7} \mathrm{CFU} / \mathrm{mL}\right)$ and SLs $(1 \times \mathrm{MIC}, 2 \times \mathrm{MIC}, 4 \times \mathrm{MIC})$ in $5 \% \mathrm{DMSO} / \mathrm{PBS}$ buffer at room temperature with constant shaking at $200 \mathrm{rpm}$. Aliquots of $20 \mu \mathrm{L}$ were withdrawn periodically at $\mathrm{t}=0,0.25,0.75,1$, and $3 \mathrm{~h}$, and a series of $10 \times$ dilutions were made before spreading onto nutrient agar plates. The agar plates were then incubated at $37^{\circ} \mathrm{C}$ for $12 \mathrm{~h}$. The killing rate was measured by comparing colonies grown on each agar plate with colony counts from the untreated control.

\subsection{Cytotoxicity Study}

The activity of SL derivatives against M1 activated macrophages (AMOs) obtained after the stimulation of Raw 254.7 (ATCC) murine macrophages with LPS (lipopolysaccharide; $1 \mu \mathrm{g} / \mathrm{mL}$ ) for 4 days was assessed following the procedure reported in the literature by us [17].

\subsection{Dye Leakage Experiment}

The disruption of bacterial membranes after treatment with LSL and SL-ester derivatives was tested using a fluorescence probe, diS-C3(5), which can be quenched by the electrically polarized membrane. B. Cereus grown to mid-log phase was adjusted to $2.5 \times 10^{6} \mathrm{CFU} / \mathrm{mL}$ in fresh MHB. Subsequently, $100 \mu \mathrm{L}$ of cell suspensions were mixed with $50 \mu \mathrm{L}$ of LSL and SL-ester solutions $(40 \mu \mathrm{g} / \mathrm{mL}, 58-60 \mu \mathrm{M})$ and $50 \mu \mathrm{L}$ of diS-C3(5) $(190 \mu \mathrm{g} / \mathrm{mL}, 348 \mu \mathrm{M})$, followed by incubation at $37^{\circ} \mathrm{C}$ for $1 \mathrm{~h}$. Polymyxin B $(100 \mu \mathrm{g} / \mathrm{mL}$, $77 \mu \mathrm{M})$, a well-characterized membrane-depolarized peptide, and PBS were used as positive and negative controls, respectively. Fluorescence data were recorded at $670 \mathrm{~nm}$ with excitation at $622 \mathrm{~nm}$ on Molecular Devices SPECTRAmax Plus 384 UV-VIS High Throughput Microplate Spectrophotometer and normalized against the negative control.

\section{Conclusions}

In summary, we designed and synthesized a library of SLs that exhibit promising antimicrobial activities against Gram-positive human pathogens with moderate selectivity (TI = 6-33). SL-butyl ester exhibited the best selectivity among all the SLs tested. Kinetic studies revealed that SL-ester derivatives kill B. cereus in a time- and concentrationdependent manner resulting in greater than a 3-log reduction in cell number within $1 \mathrm{~h}$ at $2 \times$ MIC. In contrast, LSL required $3 \mathrm{~h}$ to cause a $3-\log$ reduction in $B$. cereus. The results of a depolarization assay performed using diS-C3-(5) as a fluorescent probe revealed that, except for LSL, all structurally edited SLs show a strong ability to enhance membrane permeability. Longer carbon chain SL esters exhibit a strong depolarizing effect despite their inability to kill bacterial cells. In contrast, LSL failed to enhance membrane permeability despite its good antimicrobial activity. These results strongly suggest that, while membrane 
disruption may be involved in LSL and SL-ester antimicrobial activity, additional pathways are involved.

Author Contributions: Conceptualization, R.A.G.; Data curation, F.L.; Formal analysis, F.T. and R.A.G.; Funding acquisition, R.A.G.; Investigation, F.L.; Methodology, F.T. and F.L.; Supervision, F.T. and R.A.G.; Writing—original draft, F.T.; Writing—review \& editing, F.T. and R.A.G. All authors have read and agreed to the published version of the manuscript.

Funding: This research was funded by NSF Division of Materials Research (NSF-DMR) Biomaterials (BMAT) grant 1508422.

Data Availability Statement: Data available in a publicly accessible repository.

Conflicts of Interest: The authors declare that there are no conflict of interest.

Sample Availability: Samples of the compounds are available from the authors.

\section{References}

1. Antibiotic Resistance. World Health Organization. Available online: https://www.who.int/news-room/fact-sheets/detail/ antibiotic-resistance (accessed on 30 July 2020).

2. Antibiotic/Antimicrobial Resistance (AR/AMR): Biggest Threats and Data. CDC's Antibiotic Resistance Threats in The United States (2019 AR Threats Report). Available online: https:/ /www.cdc.gov/drugresistance/biggest-threats.html (accessed on 19 May 2021).

3. European Antibiotic Awareness Day (EAAD). European Centre for Disease Prevention and Control. Available online: https://www.ecdc.europa.eu/en/news-events/european-antibiotic-awareness-day-eaad-2020 (accessed on 19 May 2021).

4. Cooper, M.A.; Shlaes, D. Fix the antibiotics pipeline. Nature 2011, 472, 32. [CrossRef] [PubMed]

5. Hurdle, J.G.; O'neill, A.J.; Chopra, I.; Lee, R.E. Targeting bacterial membrane function: An underexploited mechanism for treating persistent infections. Nat. Rev. Microbiol. 2011, 9, 62-75. [CrossRef]

6. Felse, P.A.; Shah, V.; Chan, J.; Rao, K.J.; Gross, R.A. Sophorolipids biosynthesis by candida bombicola from industrial fatty acid residues. Enzyme Microb. Technol. 2007, 40, 316-323. [CrossRef]

7. Van Bogaert, I.N.; Saerens, K.; De Muynck, C.; Develter, D.; Soetaert, W.; Vandamme, E.J. Microbial production and application of sophorolipids. Appl. Microbiol. Biotechnol. 2007, 76, 23-34. [CrossRef] [PubMed]

8. Gorin, P.A.; Spencer, J.F.T.; Tulloch, A.P. Hydroxy fatty acid glycosides of sophorose from torulopsis magnolia. Can. J. Chem. 1961, 39, 846-855. [CrossRef]

9. Solaiman, D.K.Y.; Ashby, R.D.; Zerkowski, J.A.; Foglia, T.A. Simplified soy molasses-based medium for reduced-cost production od sophorolipids by Candida bombicola. Biotechnol. Lett. 2007, 29, 1341-1347. [CrossRef]

10. Zhang, L.; Somasundaran, P.; Singh, S.K.; Felse, A.P.; Gross, R. Synthesis and interfacial properties of sophorolipid derivatives. Colloids Surf. A 2004, 240, 75-82. [CrossRef]

11. Koh, A.; Linhardt, R.; Gross, R. Effect of Sophorolipid n-alkyl ester chain length on its interfacial properties at the almond oil-water interface. Langmuir 2016, 32, 5562-5572. [CrossRef]

12. Koh, A.; Wong, A.; Quinteros, A.; Desplat, C.; Gross, R. Influence of sophorolipid structure on interfacial properties of aqueousarabian light crude and related constituent emulsions. J. Am. Oil Chem. Soc. 2017, 94, 107-119. [CrossRef]

13. Azim, A.; Shah, V.; Doncel, G.F.; Peterson, N.; Gao, W.; Gross, R. Amino acid conjugated sophorolipids: A new family of biologically active functionalized glycolipids. Bioconjugate Chem. 2006, 17, 1523-1529. [CrossRef]

14. Shah, V.; Doncel, G.F.; Seyoum, T.; Eaton, K.M.; Zalenskaya, I.; Hagver, R.; Azim, A.; Gross, R. Sophorolipids, microbial glycolipids with anti-human imunodeficiency virus and sperm-immobilizing activities. Antimicrob. Agents Chemother. 2005, 49, 4093-4100. [CrossRef]

15. Ribeiro, I.A.; Faustino, C.; Guerreiro, P.S.; Frade, R.F.; Bronze, M.R.; Castro, M.F.; Ribeiro, M.H. Development of novel sophorolipids with improved cytotoxic activity toward Mda-Mb-231 breast cancer cells. J. Mol. Recognit. 2015, 28, 155-165. [CrossRef] [PubMed]

16. Shao, L.; Song, X.; Ma, X.; Li, H.; Qu, Y. Bioactivities of sophorolipid with different structures against human esophageal cancer cells. J. Surg. Res. 2012, 173, 286-291. [CrossRef] [PubMed]

17. Diaz-Rodriguez, P.; Chen, H.; Erndt-Marino, J.D.; Liu, F.; Totsingan, F.; Gross, R.A.; Hahn, M.S. Impact of select sophorolipid derivatives on macrophage polarization and viability. ACS Appl. Bio. Mater. 2019, 2, 601-612. [CrossRef]

18. Hardin, R.; Pierre, J.; Schulze, R.; Mueller, C.M.; Fu, S.L.; Wallner, S.R.; Stanek, A.; Shah, V.; Gross, R.A.; Weedon, J.; et al. Sophorolipids improve sepsis survival: Effects of dosing and derivatives. J. Surg. Res. 2007, 142, 314-319. [CrossRef]

19. Zhou, Q.H.; Kosaric, N. Utilization of canola and lactose to produce biosurfactant with Candida Bombicola. J. Am. Oil Chem. Soc. 1995, 72, 67-71. [CrossRef]

20. Davila, A.M.; Marchal, R.; Vandecasteele, J.P. Kinetics and balance of fermentation free from product inhibition: Sophorose lipid production by Candida Bombicola. Appl. Microbiol. Biotechnol. 1992, 38, 6-11. [CrossRef] 
21. Van Bogaert, I.N.A.; Sabirova, J.; Develter, D.; Soetaert, W.; Vandamme, E.J. Knocking out the MFE-2 Gene of Candida Bombicola leads to improved medium-chain sophorolipid production. FEMS Yeast Res. 2009, 9, 610-617. [CrossRef]

22. Bisht, K.S.; Gross, R.A.; Kaplan, D.L. Enzyme-mediated regioselective acylations of sophorolipids. J. Org. Chem. 1999, 64, 780-789. [CrossRef]

23. Koh, A.; Todd, K.; Sherbourne, E.; Gross, R.A. Fundamental characterization of the micellar self-assembly of sophorolipid esters. Langmuir 2017, 33, 5760-5768. [CrossRef]

24. Singh, S.K.; Felse, A.P.; Nunez, A.; Foglia, T.A.; Gross, R.A. Regioselective enzyme-catalyzed synthesis of sophorolipid esters, amides, and multifunctional monomers. J. Org. Chem. 2003, 68, 5466-5477. [CrossRef]

25. Peng, Y.; Totsingan, F.; Meier, M.A.; Steinmann, M.; Wurm, F.; Koh, A.; Gross, R.A. Sophorolipids: Expanding structural diversity by ring-opening cross-metathesis. Eur. J. Lipid Sci. Technol. 2015, 117, 217-228. [CrossRef]

26. Le Moual, H.; Gruenheid, S. Resistance to antimicrobial peptides in gram-negative bacteria. FEMS Microbiol. Lett. 2012, 330, 81-89.

27. Kim, K.; Yoo, D.; Kim, Y.; Lee, B.; Shin, D.; Kim, E.K. Characteristics of sophorolipid as an antimicrobial agent. J. Microbiol. Biotechnol. 2002, 12, 235-241.

28. Lang, S.; Katsiwela, E.; Wagner, F. Antimicrobial effect of biosurfactants. Eur. J. Lipid Sci. Technol. 1989, 91, 363-366. [CrossRef]

29. Gong, H.; Zhang, J.; Hu, X.; Li, Z.; Fa, K.; Liu, H.; Waigh, T.A.; McBain, A.; Lu, J.R. Hydrophobic control of the bioactivity and cytotoxicity of de novo-designed antimicrobial peptides. ACS Appl. Mater. Interfaces 2019, 11, 34609-34620. [CrossRef]

30. Stone, T.A.; Cole, G.B.; Ravamehr-Lake, D.; Nguyen, H.Q.; Khan, F.; Sharpe, S.; Deber, C.M. Positive charge patterning and hydrophobicity of membrane-active antimicrobial peptides as determinants of activity, toxicity, and pharmacokinetic stability. J. Med. Chem. 2019, 62, 6276-6286. [CrossRef]

31. Stone, N.R.H.; Bicanic, T.; Salim, R.; Hope, W. Liposomal amphotericin B (AmBisome ${ }^{\circledR}$ ): A review of the pharmacokinetics, pharmacodynamics, clinical experience and future directions. Drugs 2016, 76, 485-500. [CrossRef] 